Original Research

\title{
An Analysis of Waste Management in the Republic of Moldova: A Comparison of Rural and Urban Areas
}

\author{
Kateřina Procházková, Tatiana Ivanova*, Alexandru Muntean \\ Czech University of Life Sciences Prague, Faculty of Tropical AgriSciences, \\ Department of Sustainable Technologies, Prague, Czech Republicc
}

Received: 4 January 2018

Accepted: 16 April 2018

\begin{abstract}
The existing waste management system in the Republic of Moldova is still in a developing stage and it faces some serious problems. Therefore, this research focuses on examination the waste management situation in Moldovan rural and urban areas. It describes challenges connected to Moldovan waste management such as unauthorized landfills, illegal dumps or insufficient public services. However, the main focus is given to comparing waste management features between Moldovan urban and rural areas. For the purpose of such a comparison, a questionnaire survey about waste management characterization was run in the capital city, Chisinau, and a rural village, Vorniceni, for comparison. There were 98 respondents of this quantitative research in total. The survey results show substantial differences between waste management in Chisinau and Vorniceni. Even though the capital city has functional public service for waste collection, there are still issues regarding waste sorting. On the other hand, Moldovan rural areas often suffer from lack of any waste management at all. Specifically, Vorniceni currently has no public service of waste management, so that village residents rely on their own waste transport to nearby dumps and there are no possibilities of waste sorting and recycling.
\end{abstract}

Keywords: solid waste, sorting, recycling, landfill, Chisinau

\section{Introduction}

There is no doubt that the global production of waste is increasing. Facts that can be seen as the main causes of this massive waste expansion are high population growth and migration to cities. Other major causes are general economic and social development

*e-mail: ivanova@ftz.czu.cz or enhancement of population living standards [1]. Another critical issue, except for the generated waste amount, is waste composition. The rate of municipal solid waste is 2 billion tons worldwide [2], and this is annually increasing by $8 \%$ [3]. Also, we have seen explosive growth of plastics representation in waste composition. Since 1950 the amount of plastic waste has increased by around 280 million tonnes [4]. Therefore, an effective and sophisticated waste management system is a must, and special attention should be paid to such a challenging matter [5]. 
The Moldovan waste management system, considered a system of a developing country, has remained on the same level of development for the last 20 years [6], and it still faces problems such as environmental pollution, illegal dumping, landfill overloading, and insufficient networking of public services for waste collection, waste recycling, or proper legislative framework [7]. Several shortcomings in the Moldovan legislation can be observed in waste infrastructure on national and regional levels, thus an institutional restructuring of legal regulations covering waste collection, waste disposal, or recycling is needed [8]. Although solid waste management should fulfil basic minimum standards in order to protect the environment and even though there exist legal acts and government decisions dealing with environmental protection in Moldova. Such acts and decisions lack more thorough legislative or technical regulations in a waste management system that is causing large environmental pollution. A considerable share of this pollution begins with insufficient basic sanitary standards of waste disposal places that are usually not met, mainly in Moldovan rural areas. Although not only regulations can change the situation regarding waste management in the Republic of Moldova, special attention should be paid to increasing awareness of waste management issues among Moldovan society [9], because mainly ordinary citizens initiate new illegal dumps in places that are not secure.

Although Moldova belongs to a group of developing countries according to its GDP, it ranks among developed countries with its $540 \mathrm{~kg}$ average of annual municipal solid waste production per capita [10]. This amount fits into the average of 521.95-759.2 kilograms of annually produced waste per capita in developed countries. On the other hand, the average amount of annual waste production in developing countries is between 109.5 and $525.6 \mathrm{~kg}$ per capita [1]. There are approximately 3.98 million tonnes of waste generated annually in the Republic of Moldova [11] and subsequently disposed of according to [7] in about 3,000 illegal dumpsites all around the country from which approximately 473 landfills could not fulfil the environmental standards [12]. For comparison, the number of Moldovan authorized landfills is twice smaller (around 1.5 thousand) and they face substantial problems such as overloading and sanitation. However, it is especially in waste disposal storage where attention should be brought because of the landfilled waste high share. According to [12], less than $2 \%$ is recycled and the remaining $98 \%$ of all solid waste produced in the Republic of Moldova ends in storage places even though it contains valuable components such as plastics, glass, paper, or metal. From the fractional analysis of solid waste produced in Moldovan households, there can be seen an approximate representation of each component. Organic waste forms the largest part (55\%) of mentioned analysis, followed by plastics $(10 \%)$, paper $(7 \%)$, textiles $(5 \%)$, and others $[6,8,13]$.
There exist several dissimilarities in comparison of waste management in Moldovan rural and urban areas. An inconsiderable difference occurs in the amount of daily generated waste per capita, which is approximately three times higher in urban areas than in rural areas. However, the same rate observed in the capital city Chisinau is even four times higher than the average amount of Moldovan rural areas; concretely $1.3 \mathrm{~kg}$ per person per day [8]. Besides, from 60 to $90 \%$ of the urban population has access to the waste collection system, whereas only a minimum percentage of the Moldovan rural population is covered by any waste collection, thus most people from rural areas are personally responsible for their waste disposal [12]. Such a marginal contrast between Moldovan rural and urban conditions, all previously mentioned issues, and the fact that there is a lack of scientific articles about the waste management situation in Moldova (the only available literature describing the situation are mainly the reports of the German Corporation for International Cooperation, i.e., GIZ projects and the Ministry of the Environment of the Republic of Moldova) have led to initiation of the following broader research for analysing the waste management situation. The main objective of this research was to investigate the current situation of waste management in rural area of the village of Vorniceni and the city of Chisinau, focusing on: 1) analyzing waste sorting and recycling of waste types in Vorniceni and Chisinau; 2) determining waste production dependence on different factors such as age, sex, or place of origin; and 3) analyzing satisfaction with waste management in the two municipalities.

\section{Material and Methods}

\section{Data Collection}

The survey took place in July 2016. For the collection of primary data, different methods were used. The major part of primary data consisted of information from semistructured questionnaires, then a personal interview with the local authority in Vorniceni and observations of targeted areas. The triangulation of methods ensured a wider examination of the issue. For the purpose of rural and urban areas comparison in this research, the survey was conducted in the biggest Moldovan city, Chisinau, and the nearby village Vorniceni in a rural area selected for its proximity to the capital city, traffic accessibility, and its involvement in a project for future waste management development.

Chisinau, with its population of 685,900 inhabitants [14], is divided into 5 parts and in each of them a photo documentation of areas for waste collection was done. On the other hand, Vorniceni is a larger village with around 4,000 inhabitants [15] situated west of Chisinau. Besides the photo documentation of local waste disposal area, an interview with the village's mayor took part. Unfortunately, any contacted authority in the Chisinau 
administration did not have time to grant a personal interview.

Before the beginning of the questionnaire survey, a convenient sampling method was chosen for a questionnaire of participants' selection so anybody older than 15 years and willing to cooperate could participate. The questionnaire itself was elaborated upon in English and subsequently translated to Russian and Moldavian languages. A questionnaire test of the English version took place in May 2016 in the Czech Republic in order to adjust the form and find possible discrepancies. Despite questionnaire language translation, there was also a language barrier between the research conductor and survey participants and some literature sources unavailability in English as a limiting factor of research survey. The interview with the current Vorniceni mayor helped to clarify the waste management situation in the village and also future plans of Vorniceni to build a waste management system through participation in a project funded by the International Bank for Reconstruction and Development (altogether 23 villages from 3 Moldovan rayons applied to participate in this project).

\section{Questionnaire Survey}

The questionnaire survey part included filled out questionnaires from a total of 98 participants, where 55 respondents came from the capital city Chisinau, whereas 43 remaining respondents were inhabitants of the rural village of Vorniceni. Due to the different developments of waste management in the rural and urban Moldovan areas, there were small corrections between the questionnaires for those two areas. The questionnaire was semi-structured and it consisted of 21 questions in the case of a questionnaire for rural areas and 14 questions in the case of a questionnaire for urban areas. We incorporated multiple choice, dichotomous, and open-ended questions in both versions. Questions focused on the amount and type of produced waste, waste sorting, and methods of waste disposal, waste collection, or satisfaction with local waste management; questionnaires designed for rural areas additionally encompassed questions on farm characteristics and their waste production.

\section{Data Analysis}

The collected data set from the questionnaire survey was transcribed into the statistical program SPSS, where it was cleaned, coded, and categorized for further analysis. The confidence level for data testing was chosen to be $95 \%$. The following methods were used for testing the data set and clarifying the research questions: 1) Descriptive statistics were used to determine frequencies of every analyzed variable in order to explore the basic distribution of participants' answers before further testing; the research also examined means of particular unsorted waste types to determine a composition of respondent's waste production.

2) Crosstabulation (Chi-square test), a method used to analyze a relationship between two variables where there is an opportunity to distinguish which variable is independent and which is dependent [16], detected whether there was a relationship between a participant's age and the amount of waste he or she produces per day, and also the relationship between a participant's origin and his or her waste-sorting customs.

3) Mann-Whitney's test, a nonparametric test analyzing data from two independent samples where the data (one metric and one scale data) are not normally distributed [17]; for the purpose of this paper we examined the variable dealing with the amount of sorted waste (in percentage) as a scale variable and respondent's gender and as categorical data.

\section{Results and Discussion}

For the purpose of waste production analysis, the data of waste amount produced per person per day in kilograms were tested to find if there was a relationship between the mentioned variable and people's age, origin, and sex. Whereas according to [18] and their study in Poland waste quantity is influenced by gender and age structure, our research revealed no statistically provable relationship between the amount of waste produced and a respondent's sex. The same applies to respondent's origin, even though there exist studies like the one from [19], which claims that people from rural areas produce less waste than people living in a city. However, in the case of age, the relationship between waste production and a respondent's age was proven as statistically significant in this research and frequencies of a respondent's answers according to their affiliation to a specific age group were obtained. On the basis of data distribution, the Chi-square test and crosstabulation were used to test the following hypothesis:

\section{$H_{0}=$ Younger people and seniors produce less wa- ste than people of middle age in the Republic of Moldova.}

Pearson's Chi-square test result came out to be valuable. The $p$ value was less than 0.05 and the number of cells with value smaller than 5 was not higher than $30 \%$ ( $p=0.000 ; 8.3 \%$ of cells have expected count less than 5), and so it proved that the outcomes from Table 1 were statistically significant. The null hypothesis was confirmed, meaning that younger people and seniors really do produce less waste than people of middle age in Moldova. Similar results were found in the research of [20], where the majority of waste was produced by people between 35 and 49 years old. 
Crosstabulation (Table 1) showed more specifically that people between ages 15 and 30 years and older than 61 years are more likely to produce less than $1 \mathrm{~kg}$ of waste. On the other hand, people between the ages 31 to 60 years are more likely to produce more than $2 \mathrm{~kg}$ of waste per day, which is a higher amount than the average in the Republic of Moldova (generally $1.48 \mathrm{~kg}$ per capita). According to [8], the rate ranges between 0.3 and 0.4 kilograms in Moldovan rural areas and around $0.9 \mathrm{~kg}$ or more in urban areas. For comparison, the average amount of household waste in the Czech Republic is $0.8 \mathrm{~kg}$ [10]. A similar amount of waste was also an outcome of research conducted by [21] in the Czech Republic in 2013, where the measurement of daily waste production per person per day reached values up to $0.88 \mathrm{~kg}$ with a local fee system of payment for waste, and $0.6 \mathrm{~kg}$ with fee by act on waste system of payment for waste (there are altogether three systems of payment for waste collection in the Czech Republic and they mainly differ in the definition of a taxpayer).

Comparable data can be also seen in [13] research from 23 case studies (developing countries) where the average waste generation reached $0.77 \mathrm{~kg}$ per person per day, while European Union average equals $1.51 \mathrm{~kg}$, which is much closer to Moldova [10]. However, the amount can differ depending on the type of living. Considering the only questionnaire survey run in Vorniceni where the amount of waste was calculated together from respondent's household and a small farm, most respondents claimed they produce between 0 to $5 \mathrm{~kg}$ of waste daily.

The previous test revealed an amount of waste production among Moldovan people by their age. According to [13], age is one of three most important factors that shape recycling habits. Therefore, the Chi-square test where the results were categorized by respondent age was run again - this time on data focusing on waste sorting. The results showed that people above the age of 61 are less likely to sort their waste than people under 45 years old (the $p$ value of Pearson's Chi-Square test showed up to be equal to 0.019 and there were no cells with count smaller than 5).

Another focus of the research was to discover waste sorting and recycling habits in the rural and urban areas of the Republic of Moldova. The questionnaire survey exposed that $69.1 \%$ of respondents coming from Chisinau are used to sort waste and only $2.3 \%$ of respondents from Vorniceni sort waste. Based on these findings, the following hypothesis for waste sorting among Moldovan people was made:

\section{$H_{0}=$ People living in a city are more used to sorting out waste than people living in Moldovan rural areas.}

After running Chi-square test in SPSS, the existence of a relationship between the dependent waste sorting variable on the independent origin variable was proved, the $p$ value equaled 0.000 and the number of cells with amounts smaller than 5 equaled $0 \%$. Conducted crosstabulation demonstrated the correctness of the null hypothesis. Even though there are more people who are not used to sorting out waste $(60.2 \%$ of respondents), among people who do so (39.8\% of respondents) it is just residents of cities who are more likely to sort. Nevertheless, not everyone living in a city sorts even though there is a place for sorted waste collection in their neighborhood (only 39 of 55 survey respondents living in Chisinau marked sorting as an option about how they dispose of the waste). In contrast, as it could seem logical that residents of villages use more composting to get rid of their waste, only 2 respondents out of 43 survey participants living in Vorniceni chose composting as a treatment of their waste. Low involvement in recycling is also confirmed by [10], which says that only $1 \%$ of Moldovan waste is recycled (most of the questionnaire respondents indicated that they sort out around $10 \%$ of produced waste). Similar variables were observed in Malaysia, where the rate of recycled waste is $5 \%$ and where [22] conducted a study in which $59.9 \%$ of participants stated that they do not recycle at all. For comparison, countries belonging to the European Union recycle around 23\% of waste [10], the United States 34.5\%, China 3\% [23], and Norway $53 \%$ [24]. Even the research which was run by [21] among village residents in the Czech Republic showed results of $32.2 \%$ of sorted waste. However, we should mention that most Moldovan villages have less or no opportunities (in the form of various bins for sorted waste, for example) for their residents to do so. In fact, only $2.3 \%$ of Moldovan rural areas have a waste

Table 1. Cross-tabulation of the relationship between the amount of produced waste and a respondent's age.

\begin{tabular}{|c|c|c|c|c|}
\hline & & \multicolumn{3}{|c|}{$\mathrm{Kg}$ of waste produced per person per day } \\
\hline & & $<1$ & $1-2$ & $>2$ \\
\hline \multirow{4}{*}{ Respondents' age } & $15-30$ & $40.8 \%$ & $44.4 \%$ & $14.8 \%$ \\
\hline & $31-45$ & $25.9 \%$ & $44.4 \%$ & $29.7 \%$ \\
\hline & $46-60$ & $20.8 \%$ & $29.2 \%$ & $50.0 \%$ \\
\hline & $>60$ & $80.0 \%$ & $20.0 \%$ & $0.0 \%$ \\
\hline \multicolumn{2}{|c|}{ Total } & $39.8 \%$ & $35.7 \%$ & $24.5 \%$ \\
\hline
\end{tabular}


collection cover [12]. For instance, Poland has waste collection coverage in $80 \%$ of its territory [25].

The waste collection system in the capital city and in Vorniceni differ a lot. As noticed during personal observation of the village, Vorniceni lacks not only bins for sorted waste but there does not exist any waste collection system. In contrast, Chisinau is covered by services of a municipal enterprise, and bins for both unsorted and sorted waste are located all around the city (just their amount and type is different). All survey participants living in the city marked that they have more than 2 bins for unsorted waste in their neighborhood and there are mostly 2 bins for sorted waste (in accordance with $76.4 \%$ of respondents) or then 1 bin or zero. The most common and frequent type of bins are for plastics, then glass and paper (as confirmed by survey participants). The majority of aware respondents $(41.8 \%)$ reported that the bins for unsorted waste are emptied more than 2 times per week while in case of the bins for sorted waste the majority $(20 \%)$ stated they are being emptied once per week. On the other hand, village residents are responsible for their waste disposal as it was confirmed by the Vorniceni mayor and the questionnaire survey. In total, $33.7 \%$ of questionnaire respondents marked the option personal treatment as a way of waste collection in their locality, $30.6 \%$ of respondents stated that municipal enterprise Autosalubritate is in charge (this option was chosen only by city residents, inhabitants of Vorniceni have no such opportunity), and the rest chose do not know. Regarding waste collection system awareness, considering only respondents living in the city who are covered by a waste collection system, the survey results show that 30 out of 55 participants are aware of the waste collection company and its name, and the other 25 respondents stated that they do not know about the company or they do but they cannot recall its name. Lack of interest in the topic was revealed also in a Czech survey conducted by [21], where one-third of respondents were unaware of the system of payment for waste they belong to nor the price they pay. The survey also included a question on waste collection affordability, where $81.8 \%$ people from
Chisinau responded that the price is affordable.

Attention was paid to the difference between male and female waste sorting habits, too. In this case Mann-Whitney's test was chosen to examine means of waste amount, which is sorted (in a percentage) among two independent samples: males and females. The $p$ value came out to be 0.673 , and the null hypothesis $\left(H_{0}=\right.$ Moldovan males and females sort out the same amount of waste) was retained. Therefore, altogether there is no statistically significant difference between the amount of sorted waste which males and females produce and sort out afterwards in the Republic of Moldova. Even though for comparison research shows that males are less willing to recycle [26], like for instance, research from [21] from the Czech Republic, where females are more interested in sorting and they sort $6 \%$ more than males. Likewise, according to [27], a study from Wuhan in China, elderly females from lowincome families are generally more likely to recycle.

This research revealed the number of people who do not sort waste (even if they can or cannot) is quite alarming considering the amount of produced waste and its composition (Table 2). As the questionnaire survey disclosed, the majority of respondents produce mainly kitchen waste and plastics or other types of waste. The waste generated by survey participants is formed by approximately $57 \%$ of kitchen waste on average, but the maximum percentage of generated kitchen waste reaches values up to $92 \%$. According to [13], the average amount of $55 \%$ or greater of organic waste is consistent in developing countries; Moldovan national average representation of organic material in waste composition was $68.5 \%$ in 2005 and its predicted amount in 2020 is $55 \%$ [6]. With regards to kitchen waste amounts produced by the survey participants, composting appears to be the most efficient method of disposal. Despite this, still just a minimum of waste (amount up to $5 \%$ ) is being composted by the questionnaire respondents. In accordance with the research results, kitchen waste is then followed by other types of waste with $11.3 \%$ (including textile), and plastics that form on average $9.9 \%$ of respondents' waste (sorted by

Table 2. Descriptive statistics of waste type production in Moldova (comparison of the research and reference data in percentages)

\begin{tabular}{|c|c|c|c|c|c|}
\hline & Minimum & Maximum & Mean & Moldova 2005* & Moldova 2020** \\
\hline Plastics & $1 \%$ & $35 \%$ & $9 \%$ & $9.7 \%$ & $10 \%$ \\
\hline Paper & $1 \%$ & $30 \%$ & $7 \%$ & $5.1 \%$ & $11 \%$ \\
\hline Glass & $1 \%$ & $20 \%$ & $7 \%$ & $4.1 \%$ & $5 \%$ \\
\hline Metals & $1 \%$ & $20 \%$ & $7 \%$ & $3.1 \%$ & $4 \%$ \\
\hline Kitchen Waste & $5 \%$ & $92 \%$ & $57 \%$ & $68.5 \%$ & $55 \%$ \\
\hline Electronic Waste & $1 \%$ & $20 \%$ & $8 \%$ & - & - \\
\hline Others & $2 \%$ & $45 \%$ & $11 \%$ & $9.5 \%$ & $15 \%$ \\
\hline
\end{tabular}

*Moldovan national average in 2005 [6]

**Moldovan national average prediction for 2020 [6] 
$49.1 \%$ of survey participants from the city). This value matches the national average of plastics amount in waste composition, which reached $9.7 \%$ and its prediction for 2020 will increase only by $0.3 \%$ [6]. In comparison, Germany produced only $30 \%$ of organic waste, but $13 \%$ of plastics in 2005 [28]. However, the waste composition differs according to place, and the survey data fits into the values of [6] statistics from 2005 and the author's estimation for 2020. The only overlapping waste types are glass and metals by 2 to $3 \%$. An interesting fact about the prediction for 2020 is also the increase of paper production to double and the decreasing value of kitchen waste that is possible considering the survey data from 2016.

The waste treatment aspect was included in this survey as well and it showed that on average $82.94 \%$ of respondents' waste is disposed to mixed waste bins, $8.92 \%$ of waste is composted (only by people living in the village), $11.68 \%$ is burned, and approximately $10 \%$ end up in open dumpsites. Among the options of waste burning and dumping, the majority of respondents who chose such treatments came from the rural area. However, the amount of dumped waste should be much higher considering the fact that all the waste produced in Vorniceni ends up in an open dumpsite right next to the village, so if the waste is not composted or burned it is for $100 \%$ thrown away to the dumps. Comparing the waste disposal methods in other countries, the EU member states landfill $19 \%$ of produced waste, the United States $42 \%$, Japan $9 \%$, and Switzerland only $3 \%$ [24].

Another testing question dedicated to satisfaction with waste management in rural areas versus cities showed differences in respondents' satisfaction. 60.4\% of survey respondents were unsatisfied or they were more unsatisfied than satisfied with waste management in their locality. Therefore, the following hypothesis was established:

\section{$H_{0}=$ People from villages are more unsatisfied with waste management in their locality than people living in cities.}

The Chi-square test confirmed the reliability of the cross-tabulation results $(p=0.000$ and there were less than $25 \%$ of values smaller than 5 ). From $48 \%$ of unsatisfied respondents, the majority comes from village residents, which proves that people living in villages are more likely to be unsatisfied with waste management in their locality than people living in cities (there is no satisfied respondent in Vorniceni). Concretely, 74.4\% of villagers marked the option unsatisfied. The same trend can be seen in the option when people are more unsatisfied than satisfied. The rest of people living in Vorniceni (25.6\%) marked the option more unsatisfied than satisfied in the questionnaire. While in the case of city inhabitants, the numbers are more distributed among the answers. The total share of satisfied or more satisfied than unsatisfied respondents reached $29.6 \%$, all of them are coming from the city. If we consider only the city residents, $43.6 \%$ marked satisfied, 9.1\% marked more satisfied than unsatisfied, $27.3 \%$ chose unsatisfied, and $20 \%$ picked more unsatisfied than satisfied. Nevertheless, there exists a waste management system in the capital city, the distribution of respondents living in Chisinau proves that there remains room for improvement. This fact could be changed also by increasing public awareness of waste management among the Moldovan population. As according to [29], information takes a decisive part in the influence of people's attitude to waste management.

\section{Conclusions}

In conclusion, the situation of waste management in the Republic of Moldova depends a lot on the examined area and challenges or issues that affect this area; as it was also confirmed by the questionnaire survey conducted in the capital city Chisinau and the nearby village of Vorniceni. Waste management in Moldovan rural areas is unfortunately not so developed like in cities. During the analysis of waste production among Moldovan inhabitants, significant differences in the amount of produced waste across age groups were found. People between 31 and 60 are the group that produces the highest amount of waste per day. The major part of this waste is composed of kitchen waste and plastics. Even though there are better conditions for waste sorting and recycling in cities, and people living in villages are less likely to sort their waste, people living in cities do not embrace all options to sort out the waste completely. The results also demonstrated that there is no difference in waste sorting between male and female Moldovan inhabitants. Another analyzed factor was satisfaction with waste management where the survey revealed higher dissatisfaction among people living in villages, which is understandable considering the development of waste management in rural areas. Thus, in general there is an urgent necessity of Moldovan waste system improvement not only from the legal perspective but also by raising awareness and interest in topics dealing with waste management, waste sorting, waste recycling, and its current essential importance among Moldovan citizens.

\section{Acknowledgements}

Our study was supported by the Internal Grant Agency of the Faculty of Tropical AgriSciences, Czech University of Life Sciences Prague, in the framework of research grant No. 20175011 and No. 20185011.

Kateřina Procházková prepared the manuscript, and designed and carried out the survey; Tatiana Ivanova revised the manuscript and supervised the research; and Alexandru Muntean carried out the survey. 


\section{Conflict of Interest}

The authors declare no conflict of interest.

\section{References}

1. KARAK T., BHAGAT R.M., BHATTACHARYYA P. Municipal solid waste generation, composition, and management: The world scenario. Crit. Rev. Environ. Sci. and Tech. 42 (15), 1509, 2012.

2. ISWA. ISWA report 2015. International Solid Waste Association: Vienna, Austria, 6, 2015.

3. KOLEKAR K.A., HAZRA T., CHAKRABARTY S.N. A review on prediction of municipal solid waste generation models. Procedia Environ. Sci. 35, 238, 2016.

4. TURRA A., MANZANO A.B., DIAS R.J.S., MAHIQUES M.M., BARBOSA L., BALTHAZAR-SILVA D., MOREIRA F.T. Three-dimensional distribution of plastic pellets in sandy beaches: shifting paradigms. Sci. Rep. 4, $1,2014$.

5. VERGARA S.E., TCHOBANOGLOUS G. Municipal solid waste and the environment: A global perspective. Ann. Rev. Environ. Resour. 37, 277, 2012.

6. GAVRILITA P. Environmental systems analysis of municipal solid waste management in Chisinau, Moldova: Current situation and future perspective. Master thesis; Royal Institute of Technology: Stockholm, Sweden, 6, 2006.

7. BACAL P. The problems, achievements and trends in waste management in the Republic of Moldova. Present Environment and Sustainable Development 5 (2), 23, 2011.

8. Ministry of Environment of the Republic of Moldova, National waste management strategy of the Republic of Moldova (2013-2027); Ministry of Environment: Chisinau, Moldova, 7, 2013.

9. Humboldt Universität zu Berlin. Participatory strategic planning of solid waste management in the Republic of Moldova; SLE Publication Series S 250: Berlin, Germany, 13, 2012.

10. Ministry of Environment of the Republic of Moldova. State of the environment in the Republic of Moldova: 2007-2010. National report; Ministry of Environment: Chisinau, Moldova, 34, 2011.

11. National Bureau of Statistics of the Republic of Moldova. Generation of production and consumption waste, in territorial aspect, 2008-2016, 2016. Available online: http:/statbank.statistica.md/pxweb/pxweb/ en $/ 10 \% 20$ Mediul $\% 20$ inconjurator $/ 10 \% 20$ Mediul $\% 20$ inconjurator__MED040/MED040400reg.px/table/ tableViewLayout1/?rxid=3374a639-0c08-4daa-b3b91eb7c71aef4a (accessed on 17.02.2017).

12. HICKMAN D., GUVIR T., POPOVICI C., SOOS R., TUGUI T., TUGUI I. Modernisation of local public services in the Republic of Moldova: Intervention area 2. German Agency for International Cooperation (GIZ) project study; GIZ: Bonn and Eschborn, Germany, 4, 2014.

13. TROSCHINETZ A.M., MIHELCIC J.R. Sustainable recycling of municipal solid waste in developing countries. Waste Manage. 29 (2), 915, 2008.
14. National Bureau of Statistics of the Republic of Moldova. Resident population, as of January 1 by Cities and Years, 2017a. Available online: http://statbank.statistica.md/ pxweb/pxweb/en $/ 20 \% 20$ Populatia $\% 20$ si $\% 20$ procesele $\% 20$ demografice $/ 20 \% 20$ Populatia $\% 20$ si $\% 2$ procesele $\% 20$ demografice_POP010/POP010500reg.px/table/ tableViewLayout $1 /$ ?rxid=b2ff27d7-0b96-43c9-934b42e1a2a9a774 (accessed on 17.02.2017).

15. National Bureau of Statistics of the Republic of Moldova. Results of population and housing census in the Republic of Moldova in 2014: Characteristics - population (population by communes, religion, citizenship), 2017b. Available online: http://www.statistica.md/pageview. php?1=en\&idc $=479($ accessed on 17.02.2017).

16. MUIJS D. Doing quantitative research in education with SPSS, 2nd ed.; SAGE Publications: London, UK, 99, 2010.

17. NACHAR N. The Mann-Whitney U: A test for assessing whether two independent samples come from the same distribution. Tutor. Quant. Methods Psychol. 4 (1), 13, 2008.

18. TALALAJ I.A., WALERY M. The effect of gender and age structure on municipal waste generation in Poland. Waste Manage. 40, 3, 2015.

19. DAHLÉN L., ABERG H., LAGERKVIST A., BERG P.E.O. Inconsistent pathways of household waste. Waste Manage. 29 (6), 1798, 2009.

20. BEIGL P., LEBERSORGER S., SALHOFER S. Modelling municipal solid waste generation: A review. Waste Manage. 28 (1), 200, 2008.

21. MRLIKOVA TYDLITATOVA E., HAVRLAND B., IVANOVA T. Social awareness on waste production in rural areas. Engineering for Rural Development, 560, 2014.

22. OMRAN A., MAHMOOD A., AZIZ A.H., ROBINSON G.M. Investigating households attitude toward recycling of solid waste in Malaysia: A case study. Int. J. Environ. Res. 3 (2), 275, 2009.

23. LIU A., REN F., LIN W.Y., WANG J.Y. A review of municipal solid waste environmental standards with a focus on incinerator residues. Int. J. Sustain. Built Environ. 4 (2), 165, 2015.

24. TISSERANT A., PAULIUK S., MERCIAI S., SCHMIDT J., FRY J., WOOD R., TUKKER A. Solid waste and the circular economy: A global analysis of waste treatment and waste footprints. J. Ind. Ecol. 21 (3), 628, 2017.

25. MACIAS A., PINIARSKI W. Municipal solid waste management problems on a local scale: A case study from rural Poland. Pol. J. Environ. Stud. 25 (4), 1623, 2016.

26. MA J., HIPEL K.W. Exploring social dimensions of municipal solid waste management around the globe - A systematic literature review. Waste Manage. 56, 3, 2016.

27. LI S. Recycling behaviour under China's social and economic transition: The case of metropolitan Wuhan. Environ. Behav. 35 (6), 784, 2003.

28. MÜHLE S., BALSAM I., CHEESEMAN C.R. Comparison of carbon emissions associated with municipal solid waste management in Germany and the UK. Resour. Conserv. Recy. 54 (11), 793, 2010.

29. DIJKEMA G.P.J., REUTER M.A., VERHOEF E.V. A new paradigm for waste management. Waste Manage. 20 (8), 633, 2000. 